\title{
Results of surgical procedures for the correction of foot-drop and of lagophthalmus due to leprosy
}

\author{
M W WEBER,* A VAN SOEST, $\uparrow$ G NEFF, $\ddagger$ \\ T CHIANG§ \& R PFAU $\S$ \\ * Kinderlink der Medizinischen Hochschule Hannover, Konstanty \\ Gutschow Str. 9, D-3000 Hannover 61, Germany; †Paul Lechler \\ Krankenhaus, Tübingen, Germany; $\ddagger$ Department of Technical \\ Orthopaedics, Limb Deficiencies and Rehabilitation, Orthopaedic \\ Hospital of the Free University of Berlin, Oskar Helene Heim, \\ Berlin, Germany; §Marie Adelaide Leprosy Centre, Karachi, \\ Pakistan
}

\section{Accepted for publication 6 March 1992}

\begin{abstract}
Summary Leprosy mutilations of the muscles and skeleton can be relieved by reconstructive surgery, but evaluation of the results of these operations is seldom undertaken. Between 1975 and 1984, 59 leprosy patients were operated on at the Marie Adelaide Leprosy Centre, Karachi, Pakistan, for lagophthalmus with the transposition of the posterior tibial muscle.

We were able to re-examine 39 patients: tibialis posterior transposition was performed 25 times, and temporalis transposition was carried out 33 times; 18 of the 25 patients with the tibialis posterior transposition were pleased with the result, 7 were not: 21 patients could extend their feet above the neutral position; 24 of the patients with the temporalis transposition were satisfied, 9 were not: complete closure was demonstrated in 21 eyes; Persistent corneal damage was noted in 15 eyes; 12 of the 23 male patients cared for themselves, 16 lived with their families; 7 of the 8 female patients lived with their families.

The results of the rehabilitation, in relation to the degree of mutilation, are considered satisfactory for a developing country. These surgical procedures give a good result, provided they are followed by intensive physiotherapy.
\end{abstract}

\section{Introduction}

Since the beginning of the 1950s, the sequelae of leprosy involving the limbs and the face have been corrected by surgical intervention. After a time of euphoria, it was recognized that the permanent loss of sensation endangered the surgical result, or that other 
complications like infection or adhesions jeopardized the operative result. ${ }^{1-3}$ Only a few follow-up studies were published., ${ }^{1,4-6}$ This paper describes the results of two surgical procedures which were performed on patients with foot-drop and lagophthalmus. Both these complications are caused by the granulomatous damage of peripheral nerves (lateral popliteal and facial nerves) after infiltration by Mycobacterium leprae during the course of the disease.

\section{Patients and methods}

Every patient who received either a temporalis transposition or tibialis posterior transposition at the Marie Adelaide Leprosy Centre, Karachi, Pakistan between 1975 and 1984 has been included in the study. The principle of tendon transposition is to utilize the action of a muscle which is innervated by another nerve to replace effectively the defective function of another muscle. The procedures were performed in the following manner:

\section{Transposition of the tibialis posterior muscle in foot-drop $(T P T)^{7}$}

Before surgery, the patient must learn to innervate the posterior tibial muscle selectively, i.e. to invert the foot. The ankle joint must be sufficiently mobile. During the operation, the tendon of the posterior tibial muscle is transected as far distally as possible. It is then re-routed above the medial malleolus and around the tibia ('circumtibial route'), or the interosseus membrane is incised and the tendon of the tibialis posterior is pulled anteriorly ('interosseous route'). The tendon is split into two slips and then sutured to the tendons of the anterior tibial muscle medially and the peroneus brevis or tertius laterally, while the foot is resting in a splint in dorsiflexion. Postoperatively, the foot remains in plaster for about 6 weeks.

\section{Transposition of the temporalis muscle in lagophthalmus (TMT), Johnson's method ${ }^{8}$}

The posterior part of the temporalis muscle is identified and the fibres are separated from the tendon. A strip of harvested fascia lata of $10-\mathrm{cm}$ length is split into 2 slips and fixed to the separated part of the temporalis. The fascia slips are passed subcutaneously through both eyelids as close to the edge as possible. Both slips are sutured to the lacrimal ligament at the medial side of the eye. The patient will then close his eye through the action of the temporalis muscle when he is chewing.

In 1986, a clinical examination was done, and the patients were interviewed using the following questionnaire:

Occupation?

What do you live on (earning money, family support, public support)?

Married?

Type of accommodation and family support?

Were you satisfied with the operation? Why or why not?

Post-operative complaints?

Tibialis posterior transposition: ulcers?

Temporalis transposition: epiphora? pain? 
In TPT-patients, the foot was inspected for mutilations, ulcers, and signs of regular care. Ulcerations at the tip and the lateral edge of the foot were especially sought for. The patient was asked to lift his foot as far as possible. The gait was observed. Finally, the range of mobility of the ankle joint was measured.

In TMT-patients, the visual acuity was estimated using Landolt's rings or counting fingers. The eyelids were inspected for entropion or ectropion, and the closure of the lids was checked. Corneal lesions were noted. The corneal reflex was checked with cottonwool to get an impression of the involvement of the trigeminal nerve. Epiphora was sought for and asked about.

\section{Results}

Out of 59 operated patients 39 were available for follow up. A total of 8 patients had died, and 12 had left the country or could not be located; 8 of them were women (average age 41 years) and 31 were men (average age 47.5 years); 12 of the patients were born within present-day Pakistan, 19 came from India or Bangladesh as refugees, 7 came from Afghanistan and 1 from Iran. In total 25 tibialis posterior transpositions and 33 temporalis transpositions were performed on these patients.

\section{Tibilias posterior transposition}

This operation was performed 25 times on 22 patients -21 patients could extend the tip of the foot above the neutral position, 3 could not; 1 foot had been amputated later on (Figure 1).

The gait of 14 patients was good in a normal heel-to-toe manner, 6 of the patients showed some degree of circumduction and 5 had greater difficulties in walking, or did not walk.

The physical findings of the patients who did not have a good result, or were not content with the operation for whatever reason, are given in Table 1.

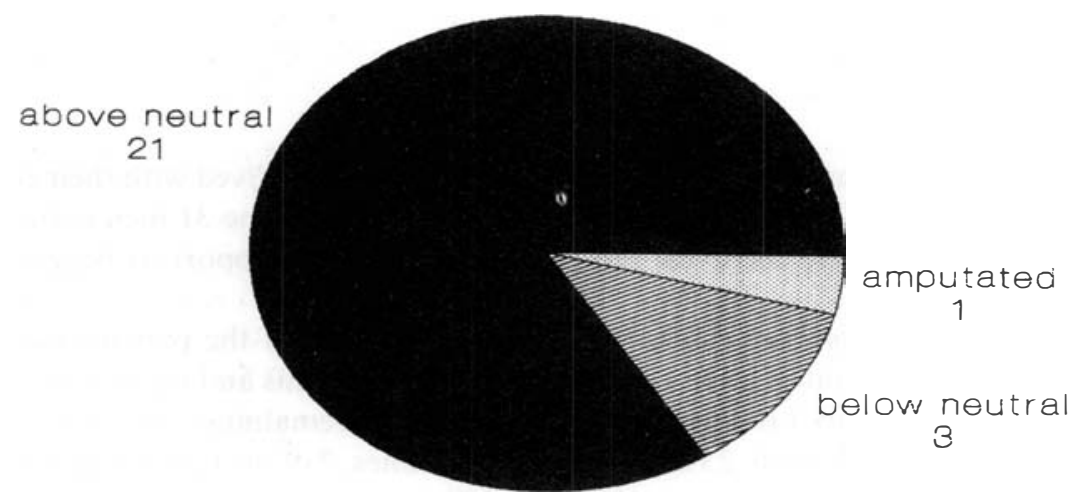

Figure 1. Tibialis posterior transposition -25 had the ability to lift the foot above the neutral position. 
Table 1. Tibialis posterior transposition. The physical findings and patients' opinion in cases not classified as a 'good result'

\begin{tabular}{|c|c|c|c|c|}
\hline Pathology of the foot & Gait* & $\mathrm{ROM} \dagger$ & $\begin{array}{l}\text { Patient's } \\
\text { opinion }\end{array}$ & Comment \\
\hline 1 Pes cavus & $\mathrm{Bad}$ & $30 / 25 / 0$ & Content & $\begin{array}{l}\text { Could work } \\
\text { No physiotherapy }\end{array}$ \\
\hline 2 Absorption of toes & Mod. & $0 / 5 / 10$ & Content & Less ulcers \\
\hline 3 Absorption of toes & Mod. & $0 / 0 / 20$ & Content & No ulcers since operation \\
\hline 4 Absorption of toes & Bad & $0 / 5 / 25$ & Content & 'Walking better' \\
\hline 5 Absorption of toes & Bad & $5 / 0 / 15$ & Content & 'Walking better' \\
\hline 6 None & Good & $25 / 0 / 0$ & Discontent & 'Ulcers healed by healer' \\
\hline 7 Neuropathic ankle & Mod. & $15 / 5 / 0$ & Discontent & 'Better before' \\
\hline 8 None & - & $5 / 0 / 15$ & Discontent & Other foot amputated later \\
\hline 9 Ulcer MTH 1 & Mod. & $0 / 0 / 10$ & Discontent & Walking tiring \\
\hline 10 Metatarsal absorption & Mod. & $0 / 0 / 10$ & Discontent & Recurrent ulcers \\
\hline 11 None & Mod. & $0 / 10 / 25$ & Discontent & Worsened again \\
\hline 12 Amputated & - & - & Discontent & Postoperative gangrene \\
\hline
\end{tabular}

\footnotetext{
* Classified as good, moderate, bad.

† ROM: range of movement documented with neutral zero method (extension (dorsiflexion)-plantarflexion).

MTH 1: first metatarsal head.
}

\section{Temporalis transposition}

The operation was performed 33 times in 22 patients - 21 eyes could be closed completely, 4 eyes showed a gap of $1 \mathrm{~mm}$, when the patient attempted to close the eye. In 3 eyes, a gap of 2 resp. $3 \mathrm{~mm}$ remained, and in 2 eyes, a gap of $4 \mathrm{~mm}$ (Figure 2).

The vision of 12 eyes was good, 10 had a moderate loss of vision, 7 had severe loss, and 4 eyes were blind. Eyes had not usually been tested preoperation. In total, 19 eyes were anaesthetic, 3 of those showed keratitis, and 7 showed a corneal ulcer or opacity. Of the 14 eyes without corneal anaesthesia, 3 had keratitis and 2 showed a corneal ulcer or opacity.

The physical findings of the eyes of patients not considered to have a good result, or when the patient had any complaints about the success, are given in Table 2.

\section{Social situation}

Of the 8 women, 4 were married and lived with their husbands, 3 lived with their relatives or children, and 1 was a beggar living on public support; 13 of the 31 men earned their living, 4 were supported by relatives, and 14 lived on public support as beggars or in leprosy homes (Figure 3).

Excluding the patients from Afghanistan, the proportion of the patients caring for themselves rises from 13 out of 31 to 12 out of 23. The 7 Afghanis and the Iranian did not live with their families, only 1 earned his own living. Of the remaining 31 patients born in Pakistan, India and Bangladesh, 23 lived with their families, 2 of the remaining 8 were not married and without relatives, but earned their own living, 3 were living in a leprosy home, and 3 were beggars. The last mentioned 6 patients were all heavily mutilated. 


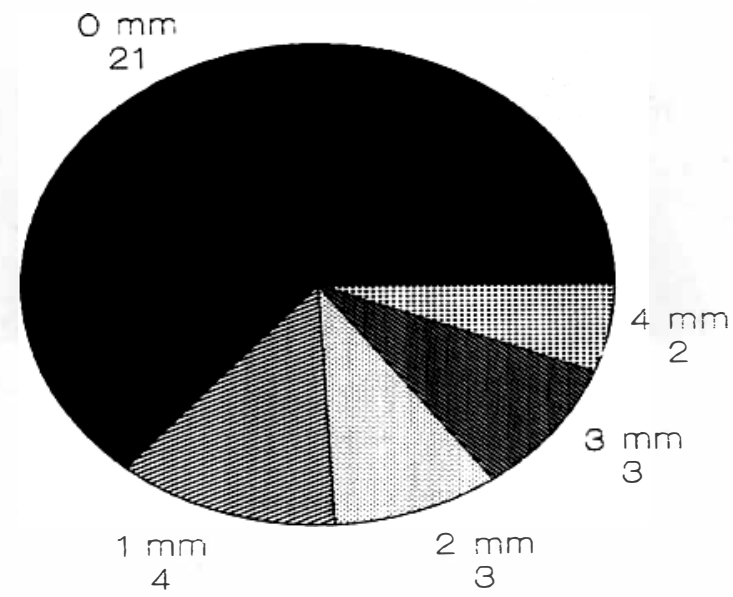

Figure 2. Temporalis transposition -33 had a gap remaining when the eyes are intended to close.

\section{Discussion}

\section{TIBIALIS POSTERIOR TRANSPOSITION}

Maximal dorsiflexion and the quality of the gait are considered to be the objective criteria for estimating the success of the operation. Selvapandian ${ }^{9}$ stated that a degree of dorsiflexion of $15^{\circ}-300^{\circ}$ is desirable. This degree was rarely achieved by the patients in this study. In our opinion, a normal heel-toe-gait without lateral deviation of the foot is possible if the foot can be raised above neutral-zero in patients with a foot without further

Table 2. Temporalis transposition. The physical findings and patients' opinion in cases not classified as a 'good result'

\begin{tabular}{|c|c|c|c|c|c|}
\hline Corneal path & $\begin{array}{l}\text { Cornal } \\
\text { anaesth. }\end{array}$ & $\begin{array}{l}\text { Gap } \\
(\mathrm{mm})\end{array}$ & Vision & Complaint & Comment \\
\hline 1 Ulcer & yes & 2 & $0 \cdot 5$ & & Persisting ulcer \\
\hline $2-$ & yes & 0 & $0 \cdot 5$ & & UL does not open completely \\
\hline $3-$ & yes & 2 & 1 & & Ectropion LL \\
\hline 4 Opacity & yes & 0 & Blind & & No epiphora \\
\hline 5 Keratitis & no & 0 & $0 \cdot 5$ & & Closing slowly \\
\hline $6-$ & yes & 0 & $0 \cdot 5$ & & Closing slowly \\
\hline 7 Opacity & yes & 0 & Blind & & Closing slowly \\
\hline 8 Ulcer & no & 4 & $<0.05$ & & Less epiphora, ectropion LL \\
\hline $9-$ & yes & 0 & $0 \cdot 5$ & Epiphora & \\
\hline $10-$ & no & 0 & 1 & Epiphora & \\
\hline 11 Keratitis & no & 1 & $0 \cdot 1$ & 'No change' & Ectropion LL \\
\hline 12 Opacity & yes & 0 & 0.05 & 'No change' & Closing slowly \\
\hline 13 Keratitis & yes & 3 & $0 \cdot 25$ & 'No change' & Epiphora \\
\hline 14 Opacity & no & 2 & Blind & Epiphora & \\
\hline 15 Ulcer & yes & 4 & 0.5 & 'No change' & \\
\hline 16 Ulcer & yes & 3 & Blind & & \\
\hline 17 Ulcer & yes & 3 & 0.05 & 'No change' & Epiphora \\
\hline
\end{tabular}

LL, lower lid; UL, upper lid 

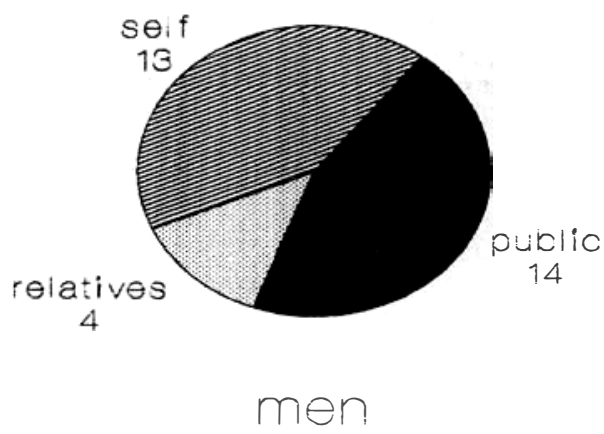

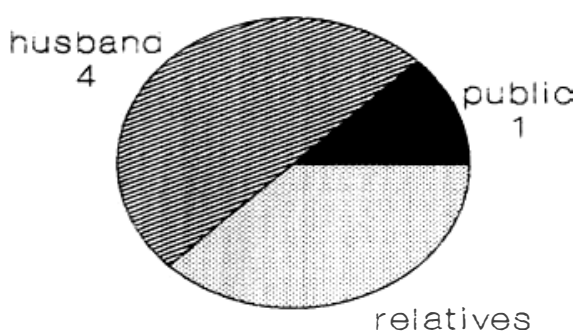

3

Figure 3. Social situation, the means of living are provided by men $(n=31)$ and women $(n=8)$.

mutilations. The higher the degree of absorption of the forefoot, the less lifting of the remaining tip is necessary.

The role of physiotherapy cannot be overemphasized. In patients who did not understand the necessity of exercise after surgery the operation proved to be useless. Ulcers will not heal without the correction of the foot-drop, but the operation alone is not sufficient to heal the ulcers themselves. Further education about correct care of anaesthetic feet is necessary.

A neuropathic joint cannot counteract the shortening muscle. An arthrodesis of the ankle joint might be more helpful to the patient.

\section{TEMPORALIS TRANSPOSITION}

From a functional point of view, we consider a remaining gap of $2 \mathrm{~mm}$ acceptable, as the cornea is moistened by Bell's phenomenon, if the patient closes his eyes frequently enough -28 of the patients achieved this, but 3 of the patients examined closed their eyes very slowly and did not seem to have enough training. Their eyes are certainly more endangered than the eyes with a small gap. Epiphora, which was a common complaint, might be due to infrequent closing of the eyes. Again, physiotherapy and education of the patient must be emphasized.

The amount of persisting damage to the cornea (15/33) is disturbingly high. In retrospect it is hard to decide whether surgery was performed too late, or if there is a need for additional eye protection.

\section{RESULTS OF REHABILITATION}

The WHO continues to demand the full professional and social integration of leprosy patients. ${ }^{10}$ According to our results, this target would seem difficult to achieve in a developing country. In Pakistan, $31 \%$ of the population make up the work force as compared to $45 \%$ in Western countries. ${ }^{11}$ With this high level of unemployment, chances for a disabled person are especially bad. In this instance, the number of 12 out of 23 male patients earning their own living represents almost the national level of employment. A 
better level of employment can only be reached by special efforts and protected workshops'.

As some of the patients develop a fixed attitude towards their disability, which prevents them from seeking work, patients should only stay away from work or should be cared for in hospitals for as short a time as is possible ('preventive rehabilitation'12).

Due to the continuous education of the public, leprosy patients in Pakistan are no longer driven away by their families: 21 of the 31 patients lived with their families, or had married and started a family of their own.

For both operations, the motivation of the patient cannot be overestimated -4 of the patients with foot-drop and 2 of the patients with lagophthalmus did not perform any physiotherapy after discharge. Provided that exercises are performed both operations give a good result. The level of employment of leprosy patients receiving surgery in this limited study is similar to the national level, thus showing a positive effect on the prevention of dehabilitation or rehabilitation of the patients.

\section{Acknowledgment}

We thank all leprosy technicians and the staff of the Marie Adelaide Leprosy Centre. For their comments we thank Professor Dr W Höfler, Tübingen, and Dr Trojan, Marburg, Germany. This project was supported in part by the German Leprosy Relief Association.

\section{References}

I Antia NH. Surgical rehabilitation in leprosy In: Leprosy, proceedings of the XI International Leprosy Congresss in Mexico City, 1978; Amsterdam 1980.

2 Browne SG. Memorandum on leprosy control. Lepra and The Leprosy Mission, London, 1983.

${ }^{3}$ Fritschi EP. Values and limitations of surgery in leprosy. Lepr India, 1976; 48 (1): 4-7.

4 Ranney DA, Furness MA. Results of the temporalis transfer for lagophthalmus. Surgical rehabilitation in leprosy and other peripheral nerve disorders. In McDowell (ed) Williams and Wilkins, Baltimore, 1974: p. 95.

5 Kulkarni VN, Mehta JM. Observations on tarsal disintegration in the cases operated for foot-drop. Indian J Lepr, 57: 598-600.

6 Richard BM. Interosseous transfer of tibialis posterior for common peroneal nerve palsy. J Bone Joint Surg $\mathrm{Br}, 1989 ; 71$ (5): 834-7.

7 Fritschi EP. Surgical reconstruction and rehabilitation in leprosy. John Wright and Sons, New Delhi, Bristol 1984.

8 Anderson JG: Surgical treatment of lagophthalmus in leprosy. Br J Plast Surg, 1961, 14: 339-45.

${ }^{9}$ Selvapandian AJ. Surgical correction of foot drop. In (ed) Surgical rehabilitation in leprosy and other peripheral nerve disorders. McDowell. Williams and Wilkins, Baltimore 1974: p. 330.

10) WHO: Expert Committee on Leprosy, Technical Report Series No. 189 Geneva 1960.

11 Ministry of Information of the Government of Pakistan. Pakistan 1984. Islamabad 1985.

12 Mehta JM: Prevention of dehabilitation in leprosy. Lepr India, 1977; 49(2): 240-6. 


\title{
Résultats des modes opératoires dans la correction chirurgicale du fléchissement du pied et de la lagophthalmie dues à la lèpre
}

\author{
M W Weber, A van Soest, G Neff, T Chiang et R Pfau
}

Résumé La chirurgie réparatrice peut remédier aux mutilations des muscles et due squelette dûes à la lèpre, mais l'évaluation des résultats de ces opérations est rarement entreprise. Entre 1975 et 1984, au Centre pour la Lèpre Marie Adélaide, Karachi, Pakistan, 59 lépreux ont été opérés de lagophthalmie par transposition du muscle temporal ou de fléchissement du pied par transposition du muscle jambier postérieur.

Nous avons pu ré-examiner 39 patients: la transposition du muscle jambier postérieur a été faite 25 fois, et celle du muscle temporal 33 fois. Parmi les 25 patients avec transposition du jambier postérieur, 18 étaient satisfaits du résultat, 7 ne l'étaient pas; l'extension du pied au-dessus de la position neutre était possible chez 21 patients. Parmi les patients avec transposition d u temporal, 24 étaient satisfaits, $9 \mathrm{n}$ el'étaient pas; on a observé la fermeture complète sur 21 yeux et un dommage persistent de la cornée sur 15 yeux. 12 des 23 lépreux se soignaient eux-mêmes, 16 vivaient avec leur famille; 7 des 8 lépreuses vivaient avec leur famille.

Les résultats de la réhabilitation, par rapport au degré de mutilation, sont considérés satisfaisants pour un pays en voie de développement. Ces modes opératoires donnent de bons résultats à condition d'être suivis d'une physiothérapie intensive.

\section{Resultados de intervenciones quirurgicas para la correccion de pie en extension y lagoftalmos debidos a la lepra}

\author{
M W Weber, A van Soest, G Neff, T Chiang y R Pfau
}

Resumen Se puede aliviar mutilaciones causadas por lepra delos músculos y del esqueleto por medio de cirugia reconstructora, pero rara vez se ef ectúa una evaluación de los resultados de tales intervenciones.

Entre 1975 y 1984, 59 pacientes leprosos fueron operados en el Marie Adelaide Leprosy Centre, Karachi, Pakistán, para lagoftalmos, por medio de transposición del músculo temporal; o para pie en extensión, por medio de transposición del músculo tibial posterior.

Nos fue posible reexaminar 39 pacientes: se realizó la transposición tibial 25 veces y la transposición del músculo temporal 33 veces; 18 de los 25 pacientes estaban contentos con el resultado de la transposición del músculo tibial, 7 no estaban contentos: 21 pacientes podían extender los pies por encima de la posición neutra; 24 pacientes estaban satisfechos con la transposición del músculo temporal, 9 no estaban satisfechos. Se observó cierre total en 21 ojos, y daño persistente de la córnea en 15 ojos. 12 de los 23 hombres pacientes se cuidaban ellos mismos. 16 vivían con sus familias; 7 de las 8 mujeres pacientes vivían con sus familias.

Se consideraron satisfactorios los resultados de la rehabilitación en relación al nivel de mutilación, para un país en desarrollo. Estos procedimientos quirúrgicos tienen buenos resultados con tal de que se proporcione una fisioterapia intensa posterior. 